\title{
Germination Characteristics and Dynamic Changes of Antioxidant Enzymes during Storage of Viola dissecta Pollen
}

\author{
Wenqing Jia ${ }^{1,2 \dagger}$, Yingzi Guo ${ }^{2 \dagger}$, Songlin $\mathrm{He}^{1^{*}}$ and Dezheng Kong ${ }^{2}$ \\ ${ }^{1}$ Henan Institute of Science and Technology, Postdoctoral Research Base, Xinxiang 453003, China \\ ${ }^{2}$ Henan Agricultural University, Zhengzhou 450002, China \\ *For correspondence: Jiawq2012@126.com; 332614899@qq.com \\ ${ }^{\dagger}$ Contributed equally to this work and are co-first authors \\ Received 16 December 2020; Accepted 08 January 2021; Published 25 March 2021
}

\begin{abstract}
Knowledge about pollen ultra-morphology, storage characteristics and germination rate are essential for directional plant breeding and plant improvement. The objective of this study was to determine a suitable medium for pollen germination in vitro of Viola dissecta and to evaluate the effect of different storage temperatures on its pollen longevity. The pollen ultramorphology of $V$. dissecta was observed using scanning electron microscopy (SEM), the suitable medium for pollen germination in vitro was determined by orthogonal test. Dried pollen of $V$. dissecta was stored at different temperatures (room temperature, $4,-20$ and $\left.-80^{\circ} \mathrm{C}\right)$ and different storage times $(24,40,72,120,184,264$ and $365 \mathrm{~d})$, the germination rate of the stored pollen and the activities of SOD, POD and CAT were investigated. Pollen grains of $V$. dissecta were medium-sized with three germination ditches. The surface ornamentation was smooth with small grains set on the surface, which was different from Viola spp. pollen. The most suitable medium for $V$. dissecta was composed of $285 \mathrm{~g} \cdot \mathrm{L}^{-1} \mathrm{sucrose}, 6 \mathrm{~g} \bullet \mathrm{L}^{-1}$ agar, $50 \mathrm{mg} \cdot \mathrm{L}^{-1} \mathrm{GA}_{3}, 250 \mathrm{mg} \cdot \mathrm{L}^{-1}$ boric acid, and $200 \mathrm{mg} \cdot \mathrm{L}^{-1} \mathrm{Ca}\left(\mathrm{NO}_{3}\right)_{2}$, The best storage temperature of pollen was $-80^{\circ} \mathrm{C}$, after 365 $\mathrm{d}$ of storage, the germination rate was still 57.86\%. During storage, the pollen germination rate decreased significantly after the peak of the activities of the three antioxidant enzymes. Correlation analysis showed that SOD was major factor affecting the germination rate of $V$. dissecta pollen, and it has a significant positive correlation with pollen germination rate, followed by CAT and POD. SOD was a sensitive antioxidant enzyme at room temperature, 4 and $-80^{\circ} \mathrm{C}$, whereas at $-20^{\circ} \mathrm{C}$, both SOD and CAT were sensitive antioxidant enzymes. (C) 2021 Friends Science Publishers
\end{abstract}

Keywords: Viola dissecta; Ultra-morphology; Pollen germination; Antioxidant enzyme activity; Storage

\section{Introduction}

Viola dissecta Ledeb is a perennial herb native to China, which belongs to the family Violaceae with palmately lobed leaf and heat resistance in China. Although $V$. tricolor and $V$. cornut has a long flowering period, but with a simple leaf shape, lower heat resistance and cold resistance, which seriously restricted their application and popularization. Due to its strong resistance to stress and aesthetic qualities, $V$. dissecta is considered to be one of the most promising plants for genetic improvement of $V$. tricolor and $V$. cornut.

Hybrid breeding technology is one of the most common means for breeding new varieties in family Violaceae (Horisaki and Niikura 2004; Guo et al. 2017). Hybrid breeding requires a large amount of high-quality pollen for pollination and fertilization (Abdullah et al. 2000; Chen et al. 2011). Therefore, the evaluation of the germination ability of the pollen after storage is the key to the success in Viola breeding (Dane et al. 2004; Kaur and Singhal 2019). In vitro germination is a commonly used technique to identify pollen viability. Pollen from $V$. dissecta is short-lived after releasing from anthers and thus pollen preservation is essential for overcoming the seasonal and geographical limitations of hybridization, and it is also an effective method to preserve plant germplasm resources. Pollen germination rate is the main indicator to evaluate the success of the storage method (An et al. 2011). The evaluation of pollen germination in vitro can validate germination in vivo (Jia et al. 2015).

Studies have shown that under different temperature stresses, the physiological balance of pollen is disrupted, resulting in excessive accumulation of reactive oxygen species (ROS) in pollen and oxidative damage to pollen cells (Cao 1986; Liu et al. 2013). Therefore, the pollen germination rate gradually decreases with the extension of storage time (Tan 2011; Qi et al. 2014; Zhang et al. 2018). The antioxidant enzymes can eliminate ROS and protect pollen to reduce damage (Guan et al. 2012; Qi et al. 2014) and the level of antioxidant enzyme activity can be used as an indicator of pollen germination to a certain extent. 
There is a correlation between pollen germination rate and antioxidant enzyme activity (Tan 2011; Zhao et al. 2004; Zhang et al. 2018; Jia et al. 2020). At present, studies on pollen of Violaceae family is mainly focused on pollen preservation of Violaceae, optimizing the medium for pollen germination $(\mathrm{Mu}$ et al. 2013) and optimizing temperature for pollen storage (Guo et al. 2017). Systematic studies on germination and storage in Violaceae pollen have not been reported and the physiological mechanism of pollen cell senescence is still elusive. The pollen viability and storage characteristics of $V$. dissecta pollen have not been reported. Therefore, in this study, pollen ultra-morphology, pollen germination rate and storage characteristics of $V$. dissecta were studied. This study aimed to determine an accurate medium for evaluating the germination of $V$. dissecta pollen, the physiological and biochemical reactions of pollen during storage were explored in terms of the antioxidant enzyme activity of pollen to provide experimental basis for selecting viable pollens for Viola interspecific hybridization.

\section{Materials and Methods}

\section{Pollen collection}

Viola dissecta flowers were collected from Taihang Mountain in Henan province, China. Flowers were collected at flowering stage before the anthers released pollen. The collected flowers were placed in an ice box, and taken back to the laboratory; the unspattered anthers were taken out of 5000 flowers, put in petri dishes and placed in a cabinet at $25^{\circ} \mathrm{C}$ for $24 \mathrm{~h}$. The pollen grains released from anthers were collected and divided into two parts: one part was used to determine the pollen germination rate and the ultra-morphology, the other part was dried for $24 \mathrm{~h}$ in a blast drying oven at $30^{\circ} \mathrm{C}$ and the dried pollen was filled and sealed in a centrifuge tube for later use.

\section{SEM observation on pollen morphology}

The pollen grains were dried in a blast dryer at $50^{\circ} \mathrm{C}$ for $6 \mathrm{~h}$, and sprayed gold with a sputter coater, then pasted the pollen grains on the sample stage with black double-sided conductive adhesive and placed under a scanning electron microscope (SEM) for observation. The shape and ornamentation of pollen grains were observed; the photos of pollen grains were taken at 500-3500 times magnification. The description of pollen morphology was mainly based on the terminology and definition of "Introduction to Palynology"(Wang and Wang 1983).

\section{Optimization of culture medium for in vitro germination of pollen}

An orthogonal experimental $\left(\mathrm{L}_{9}[3]^{4}\right)$ design was used to optimize the germination medium for $V$. dissecta pollen.
The number '4' means 4 factors ([1] sucrose, [2] $\mathrm{H}_{3} \mathrm{BO}_{3}$, [3] $\mathrm{GA}_{3}$ and [4] $\left.\mathrm{Ca}\left(\mathrm{NO}_{3}\right)_{2}\right)$, ' 3 ' means 3 levels (1) sucrose (265, 285 , and $\left.305 \mathrm{~g} \cdot \mathrm{L}^{-1}\right),[2] \mathrm{H}_{3} \mathrm{BO}_{3}\left(150,200\right.$, and $\left.250 \mathrm{mg} \cdot \mathrm{L}^{-1}\right)$, [3] $\mathrm{GA}_{3}\left(50,100\right.$, and $\left.200 \mathrm{mg} \bullet \mathrm{L}^{-1}\right)$ and [4] $\mathrm{Ca}\left(\mathrm{NO}_{3}\right)_{2}(100$, 200, and $\left.300 \mathrm{mg} \cdot \mathrm{L}^{-1}\right)$ ), and ' 9 ' means 9 trials. Each treatment was repeated three times, $\mathrm{CK}$ was the control medium (only $6 \mathrm{mg} \bullet \mathrm{L}^{-1}$ agar added). The heated and melted medium components were poured into petri dishes with a diameter of $50 \mathrm{~mm}$. After cooling and solidification, fresh pollen grains were scattered on the surface with a sterile paintbrush. The petri dishes were then placed in an incubation chamber at $24^{\circ} \mathrm{C}$ for $15 \mathrm{~h}$. Fresh pollen grain germination was assessed, and the germinated pollen grains were observed and counted by the Olympus Fluorescent Microscope BX53 at 10X magnification. A pollen grain was considered germinated if the length of the pollen tube was longer than the diameter of the pollen grain.

\section{Germination rate and antioxidant enzyme activity of stored pollen}

The dried pollen grains were divided into 4 parts and stored them at room temperature, $4,-20$ and $-80^{\circ} \mathrm{C}$, respectively. Twenty centrifuge tubes with $1.5 \mathrm{~g}$ pollens were placed at each temperature. A few pollen grains were taken out from each centrifuge tube after 24, 40, 72, 120, 184, 264 and 365 days and the germination rate was determined using the medium optimized in the experiment.

The germination rate, SOD activity, POD activity, and CAT activity of pollen grains stored at room temperature, 4 , -20 and $-80^{\circ} \mathrm{C}$ were evaluated in vitro after $24,40,72,120$, 184,264 and $365 \mathrm{~d}$. The medium was prepared with [sucrose $\left(285 \mathrm{~g} \cdot \mathrm{L}^{-1}\right)$, boric acid $\left(250 \mathrm{mg} \bullet \mathrm{L}^{-1}\right), \mathrm{GA}_{3}\left(50 \mathrm{mg} \cdot \mathrm{L}^{-1}\right)+$ $\left.\mathrm{Ca}\left(\mathrm{NO}_{3}\right)_{2}\left(200 \mathrm{mg} \cdot \mathrm{L}^{-1}\right)\right]$. Stored pollen grains at -20 and $-80^{\circ} \mathrm{C}$ were thawed in a $45^{\circ} \mathrm{C}$ water bath for $3-5$ min until the ice melted. After thawing, stored pollen grains were cultured in petri plates containing pollen germination medium in incubators. These petri plates were incubated at $25^{\circ} \mathrm{C}$ for $24 \mathrm{~h}$, and the germination of stored pollen grains were evaluated.

Antioxidant enzyme assay experiments were performed at $4^{\circ} \mathrm{C}$. A $1.0 \mathrm{~g}$ pollen was putted in a pre-cooled mortar, added $0.5 \mathrm{~mol} \cdot \mathrm{L}^{-1}$ phosphate buffer ( $\mathrm{pH} 7.0$ ), $50 \mathrm{mg}$ polyvinylpyrrolidone (PVP) and $0.1 \mathrm{~g}$ quartz, and homogenized for $30 \mathrm{~s}$. The homogenate was centrifuged at $4^{\circ} \mathrm{C}$ at $15000 \times \mathrm{g}$ for $20 \mathrm{~min}$ and the supernatant was used to determine the enzyme activity.

The activities of SOD, POD, and CAT were determined by the nitroblue tetrazolium (NBT) reduction method (Zhang et al. 2007), the Guaiacol method and the potassium permanganate titration method (Pan 2001), respectively. All enzyme assay experiments were performed 3 times.

\section{Statistical analysis}

SPSS 19.0 was used to perform statistical analysis and 
analyze the orthogonal test for pollen germination. Means grouping was done with Duncan's multiple test $(P<0.05$ or $P<0.01)$. In addition, Microsoft Excel 2016 software (USA) was used to generate figures and tables.

\section{Results}

\section{Plant and pollen morphological characteristics}

$V$. dissecta leaves were pinnate and deep-lobed, the flower was papilionaceous corolla in rose red color, with high ornamental value (Fig. 1A-C). The average length of the polar axis of $V$. dissecta pollen was $45.12 \mu \mathrm{m}$, the average length of equatorial diameter was $22.51 \mu \mathrm{m}$, and the ratio of the length of the polar axis $(\mathrm{P})$ to the equatorial diameter $(\mathrm{E})$ in $V$. dissecta pollen $\approx 2$, so the shape of $V$. dissecta pollen was spheroidal. Pollen was nearly circular in polar view, oblong in equatorial view. The pollen has three germination ditch, each with a width of approximately $3 \mu \mathrm{m}$, which dehisced from one pole to the other along the longitudinal axis (Fig. 1D-G), The ornamentation of pollen grains was smooth with small grains set on the surface, and the small cave-like carved lines had fine and curved net ridges that were more uniform but irregular in shape and size (Fig. 1H). Malformed and underdeveloped pollen accounted for $14.56 \%$ of the total pollen grains.

\section{Pollen germination in different media}

Table 1 shows that the pollen germination rate of $V$. dissecta were significantly different among 10 medium treatments $(P<0.05)$. The average pollen germination rate of No. 6 medium was $86.64 \%$ (Table 1; Fig. 2B), which was better than the control medium (CK) with only $16.11 \%$ pollen germination rate (Table 1; Fig. 2A). Boric acid was the most important factor affecting pollen germination, followed by sucrose, $\mathrm{GA}_{3}$ and $\mathrm{Ca}\left(\mathrm{NO}_{3}\right)_{2}$ (Table 1). Due to the interaction of the 4 factors, the optimal medium for pollen germination of $V$. dissecta pollen was $285 \mathrm{~g} \cdot \mathrm{L}^{-1}$ sucrose $+50 \mathrm{mg} \bullet \mathrm{L}^{-1} \mathrm{GA}_{3}$ $+200 \mathrm{mg} \cdot \mathrm{L}^{-1} \mathrm{Ca}\left(\mathrm{NO}_{3}\right)_{2}+250 \mathrm{mg} \cdot \mathrm{L}^{-1}$ boric acid (Fig. 2B), which was significantly higher than other media (Fig. 2C).

\section{Effects of storage temperatures and storage times on pollen germination}

Pollen germination rate was significantly influenced by storage temperature and time (Fig. 3). Pollen germination rate decreased gradually with increase in storage duration. The pollen rate decreased rapidly with storage time duration at room temperature, the pollen germination rate dropped to 0 , and the pollen lost vitality when stored for $120 \mathrm{~d}$. The pollen germination rate fell to 0 when stored at $4^{\circ} \mathrm{C}$ after $184 \mathrm{~d}$ of pollen storage. Under the storage conditions of -20 and $-80^{\circ} \mathrm{C}$, the germination rate of pollen decreased rapidly from $0 \sim 120 \mathrm{~d}$ of pollen storage, pollen activity showed a
Table 1: Effects of different media on pollen germination of $V$. dissecta

\begin{tabular}{|c|c|c|c|c|c|}
\hline Treatmen & $\begin{array}{l}\text { Sucrose } \\
\left(g \bullet \mathrm{L}^{-1}\right)\end{array}$ & $\begin{array}{l}\text { Boric acid } \\
\left(\mathrm{mg} \cdot \mathrm{L}^{-1}\right)\end{array}$ & $\begin{array}{l}\mathrm{GA}_{3} \\
\left(\mathrm{mg}^{\circ} \mathrm{L}^{-1}\right)\end{array}$ & $\begin{array}{l}\mathrm{Ca}\left(\mathrm{NO}_{3}\right)_{2} \\
\left(\mathrm{mg}^{-1} \mathrm{~L}^{-1}\right)\end{array}$ & $\begin{array}{l}\text { Germination } \\
\text { rate }(\%)\end{array}$ \\
\hline 1 & 265 & 150 & 50 & 100 & $41.3 \pm 1.32 \mathrm{de}$ \\
\hline 2 & 265 & 200 & 100 & 200 & $31.83 \pm 1.40 \mathrm{~g}$ \\
\hline 3 & 265 & 250 & 200 & 300 & $45.40 \pm 1.82 \mathrm{bc}$ \\
\hline 4 & 285 & 150 & 100 & 300 & $46.00 \pm 0.11 b$ \\
\hline 5 & 285 & 200 & 200 & 100 & $42.00 \pm 0.10 \mathrm{~cd}$ \\
\hline 6 & 285 & 250 & 50 & 200 & $86.64 \pm 1.30 \mathrm{a}$ \\
\hline 7 & 305 & 150 & 200 & 200 & $38.42 \pm 0.10 \mathrm{e}$ \\
\hline 8 & 305 & 200 & 50 & 300 & $34.48 \pm 1.20 \mathrm{f}$ \\
\hline 9 & 305 & 250 & 100 & 100 & $41.64 \pm 1.87 \mathrm{~d}$ \\
\hline CK & 0 & 0 & 0 & 0 & $16.11 \pm 1.13 \mathrm{~h}$ \\
\hline K1 & 39.51 & 41.91 & 54.14 & 41.65 & \\
\hline K2 & 58.21 & 36.10 & 21.49 & 52.30 & \\
\hline K3 & 30.74 & 57.89 & 39.83 & 41.96 & \\
\hline$R$ & 8.87 & 9.72 & 5.60 & 4.08 & \\
\hline
\end{tabular}

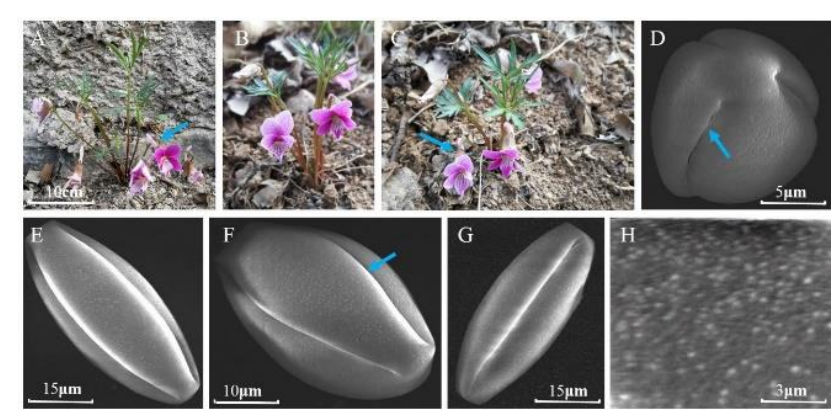

Fig. 1: Ultra-morphology of pollen grains of $V$. dissecta under the SEM. A-C: V. dissecta; D-E: Polar view; E-G: equatorial view; H: Exine sculptures

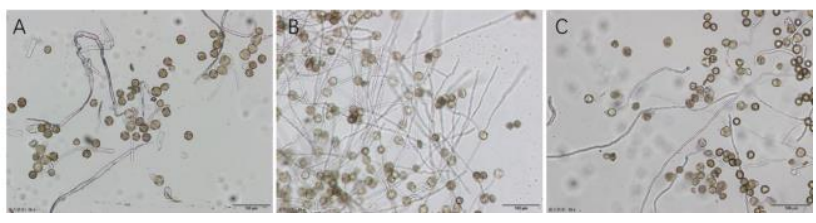

Fig. 2: Germination rate of $V$. dissecta pollen in different culture media. A: the control; B:286 $\mathrm{g} \cdot \mathrm{L}^{-1}$ sucrose, $250 \mathrm{mg} \cdot \mathrm{L}^{-1}$ boric acid $50 \mathrm{mg} \cdot \mathrm{L}^{-1} \mathrm{GA}_{3} 200 \mathrm{mg} \cdot \mathrm{L}^{-1} \mathrm{Ca}\left(\mathrm{NO}_{3}\right)_{2} ; \mathrm{C}: 305 \mathrm{~g} \cdot \mathrm{L}^{-1}$ Sucrose, 250 $\mathrm{mg} \cdot \mathrm{L}^{-1}$ boric acid, $\left.100 \mathrm{mg} \cdot \mathrm{L}^{-1} \mathrm{GA}_{3} 100 \mathrm{mg} \cdot \mathrm{L}^{-1} \mathrm{Ca}\left(\mathrm{NO}_{3}\right)_{2}\right)$

slow downward trend from 120 365 d. The pollen germination rate was the highest $(45.43 \%)$ at $-80^{\circ} \mathrm{C}$ after $365 \mathrm{~d}$ of pollen storage, which was $52.92 \%$ of the germination rate of fresh pollen, followed $(24.50 \%)$ by $20^{\circ} \mathrm{C}$. The findings of this study indicated the pollen longevity at $-80^{\circ} \mathrm{C}$ is longer than $365 \mathrm{~d}$.

\section{Pre- and post-storage changes of antioxidant activities in pollen}

SOD activity: As shown in Fig. 4, storage temperature and time had a much greater impact on SOD activity $(\mathrm{P}<0.05)$. With the extension of storage time, the SOD activity in $V$. 


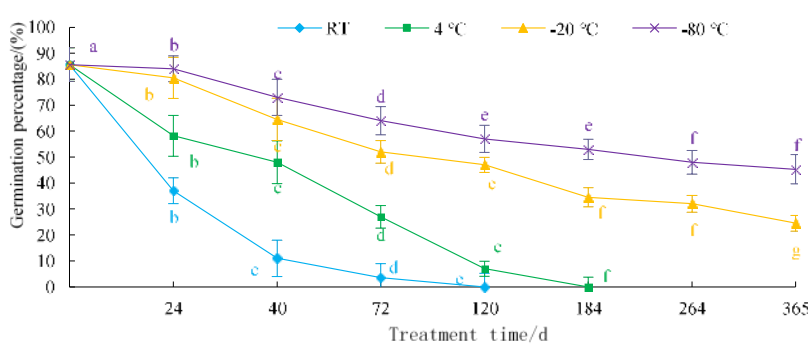

Fig. 3: Effects of different storage methods on pollen germination

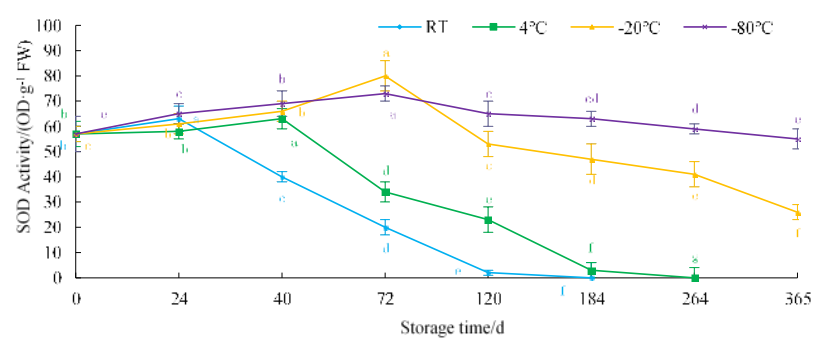

Fig. 4: Effects of different storage times and temperatures on pollen SOD activity

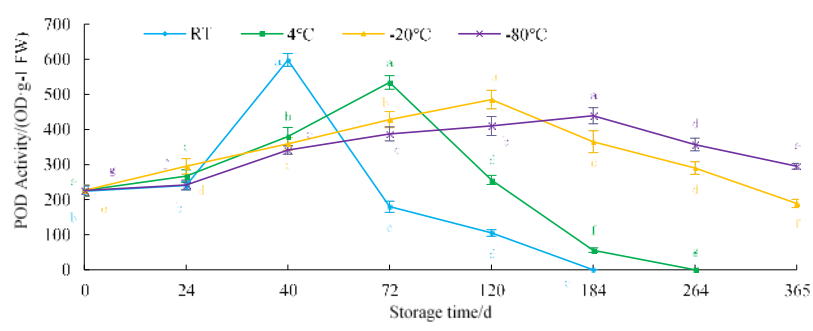

Fig. 5: Effects of different storage times and temperatures on pollen POD activity

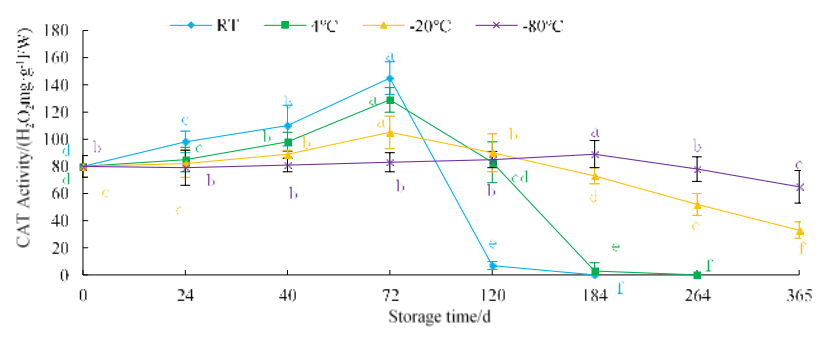

Fig. 6: Effects of different storage times and temperatures on pollen CAT activity

dissecta pollen rapidly increased, and peaked at $24 \mathrm{~d}$ at room temperature and at $40 \mathrm{~d}$ at $4^{\circ} \mathrm{C}$, and then decreased, and the SOD activity in pollen dropped to 3 after storage of $184 \mathrm{~d}$ at $4^{\circ} \mathrm{C}$, which was only $5.26 \%$ of its peak, and then declined rapidly with storage time duration, dropped to 0 at $184 \mathrm{~d}$ and at $264 \mathrm{~d}$, respectively. At $-20^{\circ} \mathrm{C}$, SOD activity increased, and reached a peak at $72 \mathrm{~d}$ of storage and then gradually declined. At $-80^{\circ} \mathrm{C}$, SOD activity went up slowly, reached a peak with $73 \mathrm{OD} \cdot \mathrm{g}^{-1}$ at $72 \mathrm{~d}$, decreasing to 60 from 72 to $120 \mathrm{~d}$ of storage, and then showed a slow decrease from $120 \mathrm{~d}$ to $365 \mathrm{~d}$, SOD activity decreased to 55 after $365 \mathrm{~d}$ of storage, which was $96.49 \%$ of that before preservation, this suggest that pollen has a strong ability to remove active oxygen.

POD activity: Under different storage time and temperature, the POD activity of $V$. dissecta pollen changed significantly (Fig. 5; $P<0.05$ ). Under $4^{\circ} \mathrm{C}$ and room temperature, POD activity showed a curve of first rapid increase and then rapid decline with the extension of storage time. After $40 \mathrm{~d}$ of storage at room temperature, POD activity reaches a peak with $598 \mathrm{OD} \cdot \mathrm{g}^{-1} \mathrm{FW}$, and then rapidly decreases, and dropped to 0 at $184 \mathrm{~d}$. At $4{ }^{\circ} \mathrm{C}, \mathrm{POD}$ activity reached a peak at 72 days and then rapidly dropped to 0 at $264 \mathrm{~d}$. At -20 and $-80^{\circ} \mathrm{C}$, the change in POD activity was similar, POD activity showed a slow increase and then a slow declining trend. Peak activity was observed with 485 $\mathrm{OD} \cdot \mathrm{g}^{-1} \mathrm{FW}$ at $120 \mathrm{~d}$ at $-20^{\circ} \mathrm{C}$, and with $439 \mathrm{OD} \cdot \mathrm{g}^{-1} \mathrm{FW}$ at $80^{\circ} \mathrm{C}$ at $184 \mathrm{~d}$, respectively. POD activity at $365 \mathrm{~d}$ decreased to $189 \mathrm{OD} \cdot \mathrm{g}^{-1} \mathrm{FW}$ and $295 \mathrm{OD} \cdot \mathrm{g}^{-1} \mathrm{FW}$ respectively, which accounted for $83.62 \%$ and $130.53 \%$ of the POD activity of pollen before storage. This indicated that pollen can eliminate $\mathrm{H}_{2} \mathrm{O}_{2}$, phenols, aldehydes, etc. to get protected from damage to maintain high viability.

CAT activity: There were significant differences in CAT activity at different storage temperatures (Fig. $6 ; P<0.05$ ). The CAT activity of $V$. dissecta pollen showed a rapid increase and then a rapid decline with storage time duration at room temperature and $4^{\circ} \mathrm{C}$. After storage for $184 \mathrm{~d}$ and $264 \mathrm{~d}$, the CAT activity dropped to 0 . The CAT activity in $V$. dissecta pollen increased first and then decreased with storage time duration at -20 and $-80^{\circ} \mathrm{C}$. Peak of CAT activity was found with $105 \mathrm{H}_{2} \mathrm{O}_{2} \mathrm{mg} \cdot \mathrm{g}^{-1}$ $\mathrm{FW}$ at $72 \mathrm{~d}$ and with $89 \mathrm{H}_{2} \mathrm{O}_{2} \mathrm{mg} \cdot \mathrm{g}^{-1} \mathrm{FW}$ at $184 \mathrm{~d}$, respectively. At $365 \mathrm{~d}$, CAT activity decreased to 65 and $33 \mathrm{H}_{2} \mathrm{O}_{2} \mathrm{mg} \cdot \mathrm{g}^{-1} \mathrm{FW}$, which accounted for 81.25 and $41.25 \%$ of the CAT activity in pollen before storage, respectively. This indicated that pollen can scavenge $\mathrm{H}_{2} \mathrm{O}_{2}$ in time at a low temperature and protect pollen from damage.

\section{Correlation of pollen germination percentage with enzyme activities}

Correlation analysis between pollen germination percentage and the three antioxidant enzymes was performed and is shown in Table 2. The pollen germination percentage in $V$. dissecta had a positive correlation with CAT and POD activities, which was significantly positively associated with SOD activity (Table $2 ; P<0.05$ ). The SOD activity played a dominant role in the pollen germination percentage during storage. The effect of SOD activity on the pollen germination was higher than that of CAT and POD activities. SOD activity exhibited a significantly positive association with POD activity or CAT activity $(\mathrm{P}<0.05)$. 
Table 2: Correlation between pollen's germination and antioxidant enzymes activity

\begin{tabular}{llcc}
\hline Antioxidants & Germination rate & SOD & POD \\
\hline SOD & $0.862^{* *}$ & & \\
POD & $0.459^{\text {ns }}$ & $0.759^{* *}$ & \\
CAT & $0.518^{*}$ & $0.726^{* *}$ & $0.784^{* *}$ \\
\hline Note: “**" indicates that the correlation $\backslash$ analysis appeared a very significant level; \\
"ns" non-significant (P>0.05)
\end{tabular}

\section{Discussion}

In this study, average size of $V$. dissecta pollen was "medium", which significantly differed from $V$. variegate, which has small pollen (Guo et al. 2017), but was in line with $V$. tricolor (Lu et al. 2005). Furthermore, compared with the pollen of other species of Viola (Jiang et al. 2000; Guo et al. 2017), the $V$. dissecta pollen has unique characteristics that specifically include the following: (1) the germination ditch was narrow, while this was wider in other species; and (2) the pollen surface was more smooth, which was different from that of Violaceae, the ornamentations of pollens surface are generally striated, wrinkled corrugated and verrucous. These differences suggest that $V$. dissecta may have a special taxonomic status in the genus Viola. According to the study of Walker (1974), the evolution of the pollen surface decoration was smooth-mesh-stripe surface wart thorn-like; indicating that $V$. dissecta was more primitive.

It is very essential to determine the requirement of pollen germination for cross-pollination (Abdelgadir et al. 2012), since different plants have different requirements for pollen germination (Huang and $\mathrm{Wu}$ 2011). It has been reported that sucrose (Kremer and Jemri'c 2006; Salles et al. 2006), boric acid (Báez et al. 2002; Zhang et al. 2018), $\mathrm{GA}_{3}$ and $\mathrm{CaCl}_{2}$ (Hirose et al. 2014) can satisfy the requirements for pollen germination and play important roles in pollen germination. Our study showed that the pollen grains of $V$. dissecta germinated even without sucrose, boric acid, $\mathrm{GA}_{3}$ and $\mathrm{Ca}\left(\mathrm{NO}_{3}\right)_{2}$, but the germination rate was only $16.11 \%$, by comparison, the germination rate of $V$. dissecta pollen ballooned with the addition of sucrose, boric acid, $\mathrm{Ca}^{2+}$ and $\mathrm{GA}_{3}$. This finding explained the germination of most pollen requires the supply of exogenous nutrients. Our study showed that the optimal medium for pollen germination of $V$. dissecta had $285 \mathrm{~g} / \mathrm{L}$ sucrose, $250 \mathrm{mg} / \mathrm{L} \mathrm{H}_{3} \mathrm{BO}_{3}, 200 \mathrm{mg} / \mathrm{L}$ $\mathrm{Ca}\left(\mathrm{NO}_{3}\right)_{2}$ and $50 \mathrm{mg} / \mathrm{L} \mathrm{GA}_{3}$ (Table 1). Excessive concentrations of sucrose, $\mathrm{Ca}\left(\mathrm{NO}_{3}\right)_{2}, \mathrm{H}_{3} \mathrm{BO}_{3}$ and $\mathrm{GA}_{3}$ inhibited pollen germination, which was in accordance with previous experiments on the pollen, including Chaenomeles sinensis (Guan et al. 2012), Camellia japonica (Jia et al. 2015). Multiple comparisons showed that boric acid was the major factor influencing the germination of $V$. dissecta pollen. Furthermore, pollen germination rate (86.64\%) correlated with pollen deformity rate $(14.56 \%)$ of $V$. dissecta (Table 1), this demonstrated that pollen deformity was the main reason why a few pollens cannot germinate.
The pollen preservation is of great importance for breeding new varieties through hybridization (Keller et al. 1996; Báez et al. 2002), low moisture content and low temperature can effectively reduce the physiological activity and nutrient consumption during pollen storage, and extend pollen longevity (Tan 2011; Liu et al. 2020). The storage pollen at $-20^{\circ} \mathrm{C}$ in sweet cherry had greater pollen viability rather than pollen those at -80 or $4^{\circ} \mathrm{C}$ (Özcan 2020). Contrasting results have been reported by Liu et al. (2020) and Jia et al. (2015) that pollen germination in Keteleeria fortunei and Paeonia qiui was superior at $-80^{\circ} \mathrm{C}$ than other temperatures. We found that pollen stored at room temperature, 4 or $-20^{\circ} \mathrm{C}$ only had a low germination rate compared with those stored at $-80^{\circ} \mathrm{C}$ in $V$. dissecta. Pollen germination rate decreased slowly at $4^{\circ} \mathrm{C}$, the pollen germination rate dropped to 0 after $184 \mathrm{~d}$ at $4^{\circ} \mathrm{C}$ (Fig. 3). This suggested that the $4^{\circ} \mathrm{C}$ was only suitable for short-term preservation of pollen. At $-80^{\circ} \mathrm{C}$, the pollen germination rate still reached $45.3 \%$ after $365 \mathrm{~d}$ of pollen storage, which was $53.17 \%$ before storage. This indicated that the longevity of $V$. dissecta pollen may be more than 12 months at $-80^{\circ} \mathrm{C}$.

SOD, POD and CAT activities are the main physiological indicators of the level of damage to plants (Miltiadis and Porlingis 1985; Cakmak and Horst 1991; Kanazawa et al. 2000). The level of antioxidant enzyme activity can reflect pollen germination ability to a certain extent (Mao et al. 2016; Guo et al. 2017; Ren et al. 2021). During pollen storage, the rapid decrease of antioxidant enzyme activity after reaching the peak often indicates a rapid decline in pollen germination rate (Akhond et al. 2000; Abdelgadir et al. 2012; Dong et al. 2017; Liu et al. 2020). Our study showed that at $4^{\circ} \mathrm{C}$, the time when the pollen germination rate drops to $0 \%$ was delayed by $80 \mathrm{~d}$ compared with that at room temperature. The activities of SOD, POD and CAT all showed a trend of first increasing and then decreasing. Compared with at room temperature, the peak time of POD and SOD activity was delayed by $16-$ $32 \mathrm{~d}$ at $4{ }^{\circ} \mathrm{C}$ storage. This showed that the accumulation of ROS in pollen at $4^{\circ} \mathrm{C}$ was slower than at room temperature, pollens produced not only reactive oxygen species but also possibly toxic substances, such as amines.

At -20 and $-80^{\circ} \mathrm{C}$, the germination rate of $V$. dissecta pollen was $45.3 \%$ after $365 \mathrm{~d}$ storage at $-80^{\circ} \mathrm{C}$, which was $53.17 \%$ of that before storage, the activities of SOD, POD and CAT were more than $80 \%$ before storage, the finding was in good agreement with that reported for Keteleeria fortunei pollen (Liu et al. 2020). This indicated that pollen has the ability to scavenge active oxygen and free radicals, and can delay pollen senescence (Xu et al. 2015). Tan (2011) reported that pollen germination rate correlated strongly with antioxidant enzymes during pollen storage. This study showed that the pollen germination rate was positively correlated with SOD, CAT and POD activities. This showed that the activity level of antioxidant enzymes could be used as indicators of pollen viability. The antioxidant enzymes played different roles at different 
storage temperatures, under room temperature, 4 and $-80^{\circ} \mathrm{C}$, the peak of SOD activity appeared earlier than POD and CAT activity. This indicated that SOD played a crucial role for protecting pollen at 3 temperatures. The peak of SOD and CAT activity first appeared at $72 \mathrm{~d}$ of storage at $-20^{\circ} \mathrm{C}$, followed by that of POD, which showed that SOD and CAT played a sensitive role at $-20^{\circ} \mathrm{C}$. In brief, SOD acted as a sensitively antioxidant role at room temperature, 4 and $80^{\circ} \mathrm{C}$, whereas SOD and CAT acted as sensitively antioxidant roles at $-20^{\circ} \mathrm{C}$.

\section{Conclusion}

Pollen surface ornamentation and size for $V$. dissecta were significantly different from Viola spp. An optimal medium composition for $V$. dissecta was $285 \mathrm{~g} \cdot \mathrm{L}^{-1}$ sucrose+200 $\mathrm{mg} \cdot \mathrm{L}^{-1} \mathrm{Ca}\left(\mathrm{NO}_{3}\right)_{2}+50 \mathrm{mg} \cdot \mathrm{L}^{-1} \mathrm{GA}_{3}+250 \mathrm{mg} \cdot \mathrm{L}^{-1}$ boric acid, resulting in a germination rate of $86.64 \%$. Boric acid was the main factor affecting the pollen germination. Storage of $V$. dissecta pollen at $-80^{\circ} \mathrm{C}$ offered a more reliable way of pollen viability preservation than storage at room temperature, 4 and $-20^{\circ} \mathrm{C}$, the pollen longevity at $-80^{\circ} \mathrm{C}$ was longer than 365 days. SOD was the main factor affecting the germination rate of $V$. dissecta pollen, followed by CAT and POD. SOD acted as a sensitively protective role at room temperature, -4 and $-80^{\circ} \mathrm{C}$, while at $-20^{\circ} \mathrm{C}$ both SOD and CAT showed sensitivity. Further studies are needed to find the possible cytological mechanism(s) of pollen programmed death in the present study.

\section{Acknowledgement}

This study was supported by The National Key Research and Development Program of China (NO.2018YFD1000401) and Henan Key Research and Development Plan (NO.202102110082).

\section{Author Contributions}

WJ SH designed the experiments; WJ, YG, YW and DK performed the experiments and analyzed the data. YG and YW prepared figures and tables.

\section{Conflict of Interest}

We, the authors, declare no conflict of interest of any kind among ourselves of the institutions where the work was done

\section{Data Availability Declaration}

All data reported in this article are available with the corresponding author and will be produced on demand

\section{Ethics Approval}

Not applicable

\section{References}

Abdelgadir HA, SD Johnson, JV Staden (2012). Pollen viability, pollen germination and pollen tube growth in the biofuel seed crop Jatropha curcas (Euphorbiaceae). S Afr J Bot 79:132-139

Abdullah YAM, HMM Abul, IM Obaidul, M Ali (2000). Cross compatibility between Abelmoschus esculentus and A. moschatus. Euphytica 114:175-180

An Y, YN Zhang, C Qian (2011). Effects of storage temperature and time on germination rate of lily pollen. J Northeast For Univ 1:44-45

Akhond MAY, MAH Molla, MO Islam (2000). Cross compatibility between Abelmoschus esculentus and A. moschatus. Euphytica $3: 175-180$

Horisaki A, S Niikora (2004). Effectiveness of insect-pollination to evaluate the level of self-incompatibility and genetic variation in Brassica rapa L. Breed Sci 54:291-295

Báez P, M Riveros, C Lehnebach (2002). Viability and longevity of pollen of Nothofagus species in south Chile. NZJ Bot 40:671-678

Cao XQ (1986). Effects of lipid peroxidation on cells and organism. $A d v$ Biochem Biophys 2:17-23

Cakmak I, WJ Horst (1991). Effect of aluminium on lipid peroxidation, superoxide dismutase, catalase and peroxidase activities in root tips of soybean (Glycine max). Physiol Plant 83:463-468

Chen JP, XH Ge, XC Yao, YH Feng, ZY Li (2011). Synthesis and characterization of interspecific trigenomic hybrids and allohexaploids between three cultivated Brassica allotetraploids and wild species Brassica fruticulosa. Afr J Biotechnol 57:12171-12176

Dane F, G Olgun, Ö Dalgiç (2004). In vitro pollen germination of some plant species in basic culture medium. J Cell Mol Biol 3:71-76

Dong B, X Zheng, H Liu, JA Able, H Yan (2017). Effects of drought stress on pollen sterility, grain yield, abscisic acid and protective enzymes in two winter wheat cultivars. Front Plant Sci 8; Article 1008

Guan Y, WQ Jia, HC Liu, ZJ Zhang (2012). Pollen viability and storage of Chaenomeles sinensis. J Zhejiang AF Univ 5:790-794

Guo YZ, JZ Wang, WQ Jia, HC Liu, SL He, JY Li, YL Wang (2018). Changes of pollen morphology, storage conditions and protective enzyme activities of Viola variegate. Plant Physiol J 4:645-650

Hirose T, H Yoichi, A Naohiro, O Masaki, Y Madoka, O Chikara, T Tomio, O Ryu (2014). Analysis of gene-disruption mutants of a sucrose phosphate synthase gene in rice, OSSPS1, shows the importance of sucrose synthesis in pollen germination. Plant Sci 225:102-106

Huang YF, XH Wu (2011). Studies on the pollen storage and viability of 3 oil-tea species. J Fujian Coll For 1:56-59

Jia WQ, SP Wang, JY Li (2015). Pollen morphology, storage condition and physiologically dynamic change during Storage of Camellia magniflora. Acta Bot Bor-Occident Sin 4:754-760

Jia WQ, YZ Guo, YL Wang (2020). Effects of storage conditions on pollen longevity of Paeonia qiui. Trans CSAE 14:307-315

Jiang GH, RL Lu, ZZ Zhou (2000). Characters of pollen and leaves epidermis in Viola from Anhui, J Univ Sci Technol Chin 5:619-626

Kanazawa S, S Sano, T Koshiba, T Ushimaru (2000). Changes in antioxidative enzymes in cucumber cotyledons during natural senescence: Comparison with those during dark-induced senescences. Physiol Plantarum 109:211-216

Kaur D, VK Singhal (2019). Meiotic abnormalities affect genetic constitution and pollen viability in dicots from Indian cold deserts. BMC Plant Biol 19; Article 10

Keller ERJ, I Schubert, J Fuchs, A Meister (1996). Interspecific crosses of onion with distant Allium species and characterization of the presumed hybrids by means of flow cytometry, karyotype analysis and genomic in situ hybridization. Theor Appl Genet 92:417-424

Kremer D, T Jemri'c (2006). Pollen germination and pollen tube growth in Fraxinus pennsylvanica. Biologia 1:79-83

Liu X, Y Xiao, Y Wang (2020). The in vitro germination and storage characteristics of Keteleeria fortunei var. cyclolepis pollen provide a reference for cross breeding. Protoplasma 257:1221-1230

Liu YP, YL Zhu, YT Ma (2013). Effects of different storage conditions on germination rate and protective enzymes activity of Magnolia liliflora Desr pollen. J Northeast For Univ 4:59-61 
Lu L, H Wang, ZX Wei (2005). Eight species of pollen morphology of clethraceae and Violaceae, with reference to relationships among six families of Dillenidae and Staphyleaceae. Acta Bot Yunnanica 3:269-278

Mao P, Y Zhang, B Cao, L Guo, H Shao, Z Cao, Q Jiang, X Wang (2016). Effects of salt stress on eco-physiological characteristics in Robinia pseudoacacia based on salt-soil rhizosphere. Sci Total Environ 568:118-123

Miltiadis V, IC Porlingis (1985). Effect of temperature on pollen germination and pollen tube growth, effective pollination period and fruit set of pear. Hortic Sci 4:733-735

Mu JY, XH Du, WQ Jia (2013). Pansy pollen viability determination and its storage method. Acta Agric Bor-Occident Sin 9:158-162

ÖZCAN A (2020). Effect of low-temperature storage on sweet cherry (Prunus avium L.) pollen quality, Hortic Sci 2:258-260

Pan RZ (2001). Plant Physiology. Higher Education Press, Beijing, China

Qi XJ, HY Ren, SM Liang (2014). Effects of storage time and temperature on the germination rates and protective enzyme activities of Myrica rubica and M. cerifera pollens. J Fruit Sci 3:460-467

Ren R, ZD Li, LL Zhang, H Zhou, XR Jiang, Y Liu (2021). Enzymatic and nonenzymatic antioxidant systems impact the viability of cryopreserved Paeonia suffruticosa pollen. Plant Cell Tiss Org Cult 144:233-246
Salles LA, JD Ramos, M Pasqual, KP Junqueira, AD Silva (2006). Sucrose and $\mathrm{pH}$ in the in vitro germination of citrus pollen grains. Ciên Agrotecnol 30:170-174

Tan JH (2011). Effects of storage temperature and storage time on germination rate and protective enzymes activity of Pinus massoniana Pollen. Sci Silvae Sin 9:28-32

Walker JW (1974). Aperture evolution in the pollen of primitive angiosperm. Amer J Bot 10:1112-1136

Wang K, X Wang (1983). Introduction to Palynology. Beijing University Press, Beijing, China

Xu J, Y Shi, Q Liu (2015). Oxidative stress and/or apoptosis of Magnolia denudata pollen after cryopreservation. Plant Physiol J 6:916-920

Zhao WF, SY Xing, YX Jiang (2004). Effects of storage time on germination percentage and protective enzymes activity of Ginkgo biloba pollen. $J$ Wuhan Bot Res 3:259-263

Zhang FQ, YS Wang, ZP Lou, JD Dong (2007). Effects of heavy metal stress on antioxidative enzymes and lipid peroxidation in leaves and roots of two mangrove plant seedlings (Kandelia candel and Bruguiera gymnorrhiza). Chemosphere 67:44-50

Zhang SL, JL Zhang, BB Chen, WT Huang, CZ Zhang, CQ Huang (2018). Review on nature and distant hybridization of rhododendron. $J$ Hunan Ecol Sci 1:33-39 